IRA-International Journal of Management \& Social Sciences

ISSN 2455-2267; Vol.12, Issue 02 (August 2018)

Pg. no. 25-30.

Institute of Research Advances

http://research-advances.org/index.php/RAJMSS

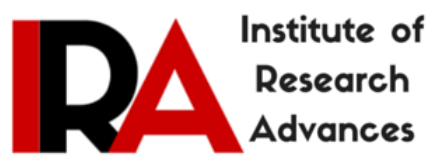

\title{
Satisfying Service Customer through a Strong Service Strategy
}

\section{Gurpreet Kaur Chhabra}

Assistant Professor, Management Education \& Research Institute (MERI), New Delhi, India.

Type of Review: Peer Reviewed.

DOl: http://dx.doi.org/10.21013/jmss.v12.n2.p2

How to cite this paper:

Chhabra, G.K. (2018). Satisfying Service Customer through a Strong Service Strategy. IRA-International Journal of Management \& Social Sciences (ISSN 2455-2267), 12(2), 25-30. doi:http://dx.doi.org/10.21013/jmss.v12.n2.p2

\section{(C) Institute of Research Advances.}

\section{(cc) EY-NC}

This work is licensed under a Creative Commons Attribution-Non Commercial 4.0 International License subject to proper citation to the publication source of the work.

Disclaimer: The scholarly papers as reviewed and published by the Institute of Research Advances (IRA) are the views and opinions of their respective authors and are not the views or opinions of the IRA. The IRA disclaims of any harm or loss caused due to the published content to any party.

Institute of Research Advances is an institutional publisher member of Publishers International Linking Association Inc. (PILA-CrossRef), USA. The institute is an institutional signatory to the Budapest Open Access Initiative. Hungary advocating the open access of scientific and scholarly knowledge. The Institute is a registered content provider under Open Access Initiative Protocol for Metadata Harvesting (OAI-PMH).

The journal is indexed \& included in WorldCat Discovery Service (USA), CrossRef Metadata Search (USA), WorldCat (USA), OCLC (USA), Open J-Gate (India), EZB (Germany) Scilit (Switzerland), Airiti (China), Bielefeld Academic Search Engine (BASE) of Bielefeld University, Germany, PKP Index of Simon Fraser University, Canada. 


\begin{abstract}
Services require a lot of customer interaction and involvement. Research in the field of service marketing suggests that this particular sector mainly earns profit from customer retention. Therefore the need of the hour is to design a strong service strategy. It is easy to get a customer through strong advertising or publicity efforts but retaining customers and keeping them delighted is almost impossible for any firm. Therefore they have to continuously keep on innovating in order to understand and surpass the rising customer expectations. But still at times despite of the best efforts of company or service staff some customers due to some or the other reason become dissatisfied with the service firm and as a result stop patronizing and change their loyalty and move to other competitive firms. It is very essential to recover such defected customers. There are certain strategies which, if religiously adopted by the service firms can not only help them bring back the defected customers but also equip them in preventing customer defection at first place itself. In this article an attempt has been made to highlight the essential elements and steps involved in designing and delivering effective and efficient customer service strategy.
\end{abstract}

Key words: Service Reliability, Service Surprise, Service Recovery, Service Fairness, Service Strategy, Customer Retention, Customer churn

\title{
INTRODUCTION
}

Look around, you will notice how the services have touched almost every aspect of your life. As the day begins the milkman, newspaper deliverer, house maid, cleaner, sweeper etc. all has a service to deliver to you. Imagine your life without these services and service providers? You wouldn't have been able to earn your livelihood if your school and college wouldn't have given you education. Can you ever forget your teachers and professors? When you eat out or even stay out of home in a hotel you are actually availing the services from one of India's fastest growing sectors, the hospitality industry. Your latest mobile handset is actually a gadget that has been made useful by telecommunication services provided by the service provider. When you go for shopping the sales person attends to you in a courteous and helpful manner. That is a service. Your bank gives you financial services. Your doctor, saloon and gym guys provide you healthcare services. Your insurance agent is also providing you services. Even when you get your car wash or serviced or get your clothes dry cleaned all these are services provided to you. When you buy electronic items or automobiles one of the most important aspects of a product offer that you look for in a given market offering, is the after sales service. For a long time now we have been too engrossed with marketing of products that we have forgotten that there is a completely new set of rules that apply to marketing of these in- dispensable set of activities known as services. Services possess four inherent characteristics not found in goods. These characteristics are: intangibility, perish ability, inseparability and variability. These characteristics create unique challenges for services. In order to attract new customers and to keep current customers coming back, service firms must find ways to meet these challenges.

The service sector has now become a vital component of the Indian economy. This sector, accounts for around $66 \%$ of the country's gross domestic product (GDP). The service sector has emerged as one of the largest and fastest growing sectors not just in the country but in the global landscape. This sector is expected to grow at a healthy rate of 5.6\% (according to National Council of Applied Economic Research ,NCAER). In India this sector comprises of various activities that includes trading, transportation, communication, financial, real estate and business services. Apart from these there is community, social and personal services available too.

\section{IS BEHAVIOR OF A SERVICE CUSTOMER DIFFERENT FROM A PRODUCT CUSTOMER?}

The answer is a big 'YES'. As mentioned earlier there are many aspects that differentiate a service from a product. It is hence evident that the behavior, expectations and satisfaction level of a customer is different when he/she buys a product and is entirely different and is based on totally different parameters when the same customer avails a service from a service marketer. This is so because services show some characteristic differences such as: 
1) INTANGIBILTY- lack of tangible assets that can be touched, seen or smelled prior to the purchase. Services vary in the degree to which they are intangible; however, for most services there are tangible items that are used to perform the service.

2) PERISHABILITY- means that services are to be consumed as soon as they are produced. In other terms we can say that services cannot be stored or inventoried.

3) INSEPARABILITY - the simultaneous production and consumption of services is known as inseparability. While goods can be produced and then sold at a later time; services can't do so.

4) VARIABILITY - this unique aspect of services refers to the sporadic or random levels of service quality customers receive when they patronize a service. The main cause of this variability in services in yet again its dependence on human element. At times, however this variability is caused due to malfunctioning of machines that causes variations in the service.

To overcome these barriers and to make customer experience a memorable one, service marketers have to design sound, effective and efficient service strategy that not only helps them create an experience of customer delight but also serve as a source of competitive advantage over the competitors.

\section{DESIGNING SERVICE STRATEGY}

A service strategy is the focal point or the point of origin in a service life cycle. It helps in the designing, developing and implementation of service product. It also helps a service organization to compete in the market. A properly designed service strategy can help a firm in creating value for the customers, designing service offer $\&$ portfolio, defining the service market, managing variable service demand and ensuring appropriate return on investment. The core elements of a service strategy are:

a) SERVICE RELIABILITY - reliability means accurate and dependable service, in other words reliability means keeping the promise that was made to the customer. By providing reliable service to the customer, a service firm can ensure accuracy and dependability and therefore prevent many errors that can be caused due to carelessness. Hence a service firm should continuously strive to develop reliability as an attitude and incorporate it as one of the core values of its business strategy. Service reliability is achieved through design dependability and accuracy that can be integrated into service system because research indicates that only $25 \%$ of mistakes in service delivery occur due to carelessness. $75 \%$ of mistakes are caused by the complicated and failure prone service systems. Therefore it is essential for a service firm to work upon its service delivery design and try to make it is such a way that it ensures accuracy and delivers what actually is promised to the customer. Thereby ensuring reliability that the customer will get the same level and quality of service each time he/she visits the firm. This will help service firms to overcome the problem of variability.

b) SERVICE SURPRISE- means finding ways to make customer delighted. In other words findings new ways or methods to give the customer a little extra, up and above his/her expectations. It is like surprising the customers in a way that he/she feels special. This could be; providing details to the customers, some firms use minute details to brief about the service process to the customer and this how they make themselves different and special from their competitive firms. This gives a "WOW" experience to the customer. In simple words it is, finding ways and methods to do those little things for the customers that not only pleases them but also leaves a mark in their mind. These small things are done with customer interest uppermost in mind instead of company profit being the priority. Such companies know it very well that customer often remembers when service providers go out of their way to help them or situations when they refuse to give up until a persistent problem is solved upto customer satisfaction. 
c) SERVICE RECOVERY - in case the customer confidence is lost, which is often the case with service firms it is essential to regain this lost confidence. Service recovery basically means removing the deficiency in your service. It means standing behind the service. Effective recovery is critical for the success of any service firm because several research findings reveal that customers in general are far more forgiving of a service failure when company makes a sincere, committed and focused effort to resolve the problem. Even if the problem is not completely resolved still customers remember the efforts done by the firm or employees. Similarly satisfactory recovery service sharply increases customer's willingness to recommend the firm and significantly improves their perceptions of overall service quality.

d) SERVICE FAIRNESS- ensures that the business is conducted in a fair or ethical way. Every customer expects the service firm to treat them in a fair and ethical way in case they perceive it to be otherwise they get angry, agitated and become mistrustful. In today's highly competitive world service companies or employees may get tempted to lure customer by making false or deceptive promises and when the truth is revealed the customer feels helpless. Though the customer may be trapped or duped once but he/she may become cautious not only with the same firm but also with other such firms in future and may even warn others about the same. Service firms must remember that fairness is not a separate dimension of service but rather touches all customer expectations.

Service firms must keep in mind some simple facts about service consumer behavior. a) Customers expect service companies to keep their promises (reliability),b) They want clean and comfortable service facilities (tangibles), c) they want prompt service (responsiveness), d) they expect the service staff to be competent and courteous (assurance), e) finally they desire the service firm to extend a caring and individualized attention to them (empathy).

\section{DESIGNING A SERVICE STARTEGY}

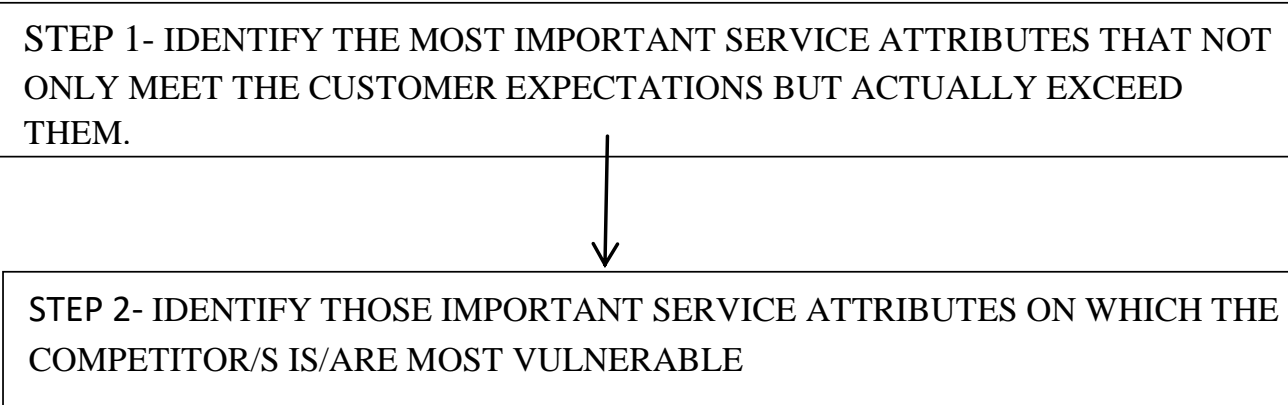

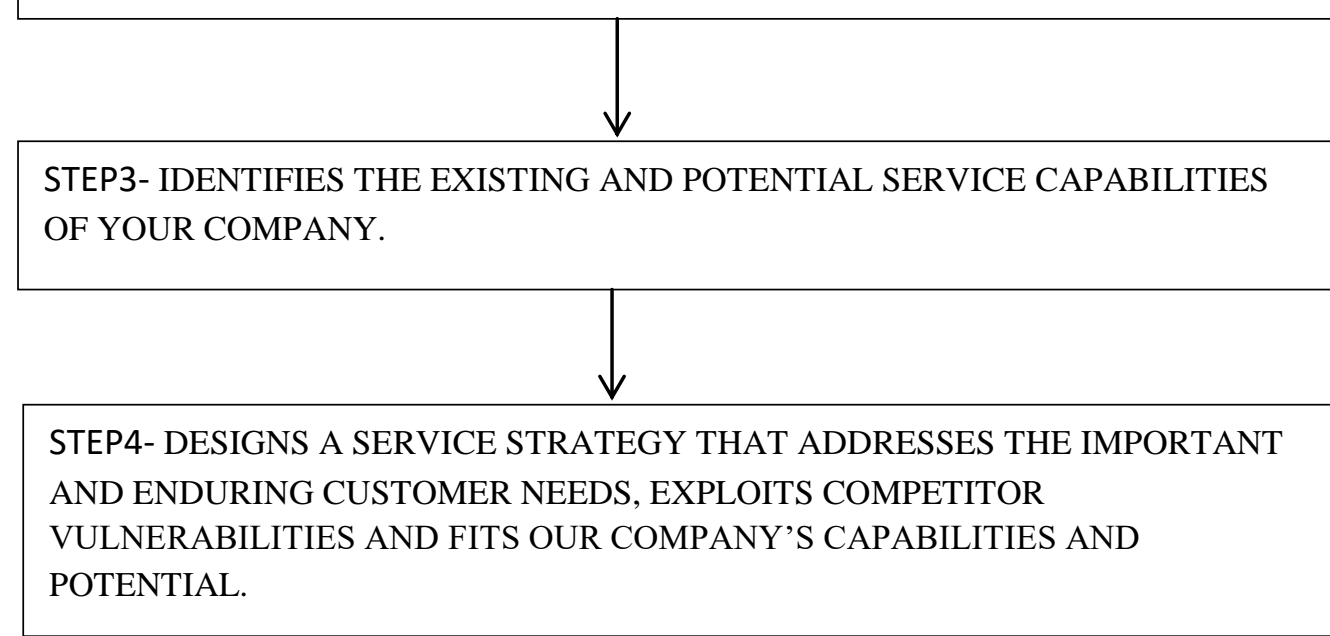




\section{HANDLING CUSTOMER COMPLAINTS: THE MOST CRUCIAL ASPECT OF A SERVICE STRATEGY}

Handling customer complaints is the most challenging and cumbersome task for a service marketer. Although majority of companies follow strict code of conduct while handling them yet certain set rules if appropriately designed and implemented as a code of conduct in service firms, can help these firms overcome the customer churn and lead to high customer satisfaction and ultimate customer retention. Following are a set of Golden rules if adopted can help a service firm overcome customer defection and reduce customer churn out rate.

RULE 1- Design and develop a suitable strategic plan- according to this strategic plan, each complain should be taken as an opportunity in disguise or a gift given to you by the customer. Consider yourself lucky that the customer is prepared to give valuable feedback for the betterment of your organization.

RULE 2- Provide training to the management and service staff in handling complaints and complaining customers in appropriate manner- train them in such a manner that they feel confident in handling complaints and difficult customers. Give them sufficient support in doing this, whenever or wherever it is possible. Make them realize the importance of excellent complaint handling in providing great customer service.

RULE 3- Enough authority and priority should be given to customer complaints and there handling- make your staff aware that complaint handling is a top priority for your operation and anyone who deals with them would be given suitable and sufficient authority as per the condition, to resolve them completely.

RULE 4- Ensure that you can process complains from all possible sources- a complain can come four possible sources viz. email/internet, telephonic call, in person and mail/post. It is very essential that the staff should be well informed and well trained in ability to handle complain from all these sources. Firm can deploy different staff or team members for handling complaints coming from different sources. For example customer care centre for handling telephonic complains, e-consumer cell for handling complains coming through email or internet and front desk consumer care team for handling complainants who visit personally.

RULE 5- Set up a process to $\log \&$ analyze all complaints and share with everyone- a lot about problems can be learnt through internal operational processes, training programs, specific employees or managers etc. through proper and detailed complain handling and analyzing procedure.

RULE 6- Appropriate complaint handling procedure- first of all thank the customer for complaining because he/she is spending his/her time and money to let you about problem. Secondly, say that you are sorry that the problem has occurred. By saying so you are not admitting your guilt, In fact your behavior is a display of good mannerisms. Thirdly, empathize with the customer this will give you instant advantage with the customer. Fourthly start your conversation with the customer with the view that customer has a valid point. You may not accept it in front of the customer directly (doing so may make the customer overpower you) but doing so internally will trigger off ideas for an acceptable resolution of the customer complain.

RULE 7- First get all the facts in place- let the customer provide all the details and the information first. This will help you understand the situation properly and accordingly pacify the emotions of the customer.

RULE 8- Rectify the mistake in case it has actually occurred- instead of using free gifts or vouchers to pacify aggrieved customers, try to fix the problem if it is possible for you to do so.

RULE 9- Make sure that your idea of the right solution to the problem should be the same as that of the customer's viewpoint regarding the same.

RULE 10- Learn from every complaint- make sure that every complaint and its subsequent handling procedure should be a lesson for you that can be used as learning for future references. At the same time let the 
complaining customer know that he/she has helped you in resolving a problem. The customer will feel privileged and happy and will surely come back again and again.

\section{CONCLUSION}

To be a successful service marketer one must understand the process and importance of a good service strategy. It's not only important to design a good strategy but is also equally important to ensure its implementation. The most important aspect of a service strategy is a strong complaint handling procedure therefore a service marketer must ensure that following are ensured: Try to minimize all possible reasons for complain. Always respond to complaints received, within $48 \mathrm{hrs}$ of receiving them. Take time from the customer for solutions, if required. Always keep your ears open for the suggestions coming from the staff. As far as possible, set examples of excellent complaint handling to lead way for the other staff members. Service strategy is more of an art and less of science therefore attitude of the service manager and that of the service staff makes a lot of difference in effective implementation of the service strategy.

\section{References}

[1] Service marketing,2e by Kenneth E. Clow and David L. Kurtz Biztantra publishers

[2] Chhabra, G.K. (2015). Consumer Behaviour. $1^{\text {st }}$ ed., Biztantra Publishers , New Delhi, India.

[3] www.studymarketing.org

[4] www.marketingdonut.co.uk 